and misinterpretations are common..$^{6-8}$ On the other hand, increased knowledge may not be sufficient to change a patient's behaviour over taking drugs. For example, a patient education programme for hypertension had no effect on compliance, though it did increase the patients' knowledge of the disease and its treatment. ${ }^{9}$ Similarly, pharmacist's instructions and an instruction card with information on the drug regimen did not increase compliance in patients for whom a 10-day course of penicillin was prescribed. ${ }^{10}$ The effect of such information may be limited by being presented in a form which is not easily understood by the patient. ${ }^{11}$ The tailoring principle that we also used was included in a more complex programme in patients with hypertension which resulted in increased adherence to the prescribed drug regimen. ${ }^{12}$

Further studies are needed to evaluate patient education and tailoring programmes for patients on different kinds of longterm medication. When considering the feasibility of introducing a patient education and tailoring programme in routine practice doctors should recognise the extent to which their diagnostic and therapeutic efforts are wasted because of nonadherence to the drug treatment prescribed.
I am indebted to Dr Per-Arne Granstrom and the staff of the eye clinic at Huddinge University Hospital for their co-operation.

\section{References}

1 Stewart, R B, and Cluff, L E, Clinical Pharmacology and Therapeutics, 1972 , 13, 463 .

${ }^{2}$ Sackett, D L, et al, American Heart fournal, 1977, 94, 666.

${ }^{3}$ Stason, W B, and Weinstein, M C, New England fournal of Medicine, 1977, 296, 732.

${ }^{4}$ Armitage, P, Statistical Methods in Medical Research, p 120. New York, Wiley, 1971.

${ }^{5}$ Sackett, D L, and Haynes, R B, editors, Compliance with Therapeutic Regimens. Baltimore, Johns Hopkins University Press, 1976.

6 Bain, D J G, Medical Education, 1977, 11, 347.

' Hellström, K, and Leijd, B, Läkartidningen, 1976, 73, 968.

${ }^{8}$ Hermann, F, American fournal of Hospital Pharmacy, 1973, 30, 155.

${ }^{9}$ Sackett, D L, et al, Lancet, 1975, 1, 1205.

${ }^{10}$ Linkewich, J A, Catalano, R B, and Flack, H L, Drug Intelligence and Clinical Pharmacy, 1974, 8, 10 .

${ }^{11}$ Ley, P, Jain, V K, and Skilbeck, C E, Psychological Medicine, 1976, 6, 599.

12 Haynes, R B, et al, Lancet, 1976, 1, 1265.

(Accepted 2 August 1979)

\title{
Bronchodilator effect of sodium cromoglycate and its clinical implications
}

\author{
J T N CHUNG, R S JONES
}

\section{Summary and conclusions}

The bronchodilator effect of sodium cromoglycate (SCG) solution was investigated. Twenty asthmatic children aged 6-15 years (mean 11.3) were examined and the action of SCG compared with that of salbutamol and placebo (water). SCG produced a significantly raised peak expiratory flow rate (PEFR) before exercise, which reached a maximum immediately after exercise. The bronchodilatation was sustained for up to four hours, when the PEFR was still significantly above the resting value. This effect was comparable in degree and duration with that of salbutamol. In contrast, placebo produced insignificant bronchodilatation before exercise but significant albeit short-lived bronchodilatation after exercise, which is the characteristic response of the asthmatic to a short period of exercise.

This powerful bronchodilator action of SCG and its equally potent inhibitory action on exercise-induced bronchoconstriction was achieved by administering the solution via an efficient nebuliser. In order to achieve maximum clinical effect the SCG must, therefore, be given in this form.

\section{Introduction}

Sodium cromoglycate (SCG) is now an established drug in the

\footnotetext{
Respiratory Unit, Alder Hey Children's Hospital, and the Institute of Child Health, University of Liverpool, Liverpool

J T N CHUNG, MB, DCH, research assistant, respiratory unit

R S JONES, MD, FRCP, consultant paediatrician, Alder Hey and Royal Liverpool children's hospitals
}

prophylactic treatment of asthma. It selectively suppresses the specific immunological pathways leading to the release of certain chemical mediators of immediate hypersensitivity and has been said to have no bronchodilator property. ${ }^{1}$ The inhibitory action of SCG on exercise-induced bronchoconstriction is well documented, but its bronchodilator properties are less well defined. Morton and Fitch ${ }^{2}$ in a report on the inhibition of exercise-induced bronchoconstriction by SCG powder found some bronchodilatation before the start of exercise but did not comment on it. Godfrey and König ${ }^{3}$ studied the inhibition of exercised-induced bronchoconstriction using various drugs and showed incidentally that there was an insignificant rise in peak expiratory flow rate (PEFR) after the inhalation of SCG powder at rest but a significant degree of bronchodilatation during exercise. Silverman and Andrea ${ }^{4}$ in a similar study of bronchoconstriction reported the enhancement of the bronchodilating action of exercise by prior inhalation of SCG powder. They commented that SCG could be used in place of bronchodilator aerosols for immediate effect.

We investigated the bronchodilator effect of SCG by using the solution, as we have found it to be superior to powder in its inhibitory action on exercise-induced bronchoconstriction. ${ }^{5} \mathrm{We}$ compared the action of SCG with that of salbutamol.

\section{Subjects and methods}

We studied 20 asthmatic children (three girls, 17 boys) aged 6-15 years (mean 11-3). Most were atopic subjects who reacted to skin tests with a variety of allergens and had a family history of atopy. Six also had eczema. Short exercise consisting of one minute of vigorous running on a flat corridor was performed on three separate days: after administration of salbutamol from an inhaler on one day, SCG solution on another, and placebo ( $4 \mathrm{ml}$ water) on a third day (these last two delivered by a mains-driven Wright nebuliser). The rate of flow of air through the nebuliser was $10-121 / \mathrm{min}$, and administration was continued until all the SCG solution had been nebulised. The dosage received by the subjects' lungs from one ampoule of solution is likely to have been appreciably higher than that received from one capsule 
of powder. In order to achieve maximal effect six puffs of salbutamol were given over five minutes and $40 \mathrm{mg}$ of SCG solution were used.

On each occasion the PEFR was recorded at rest, immediately after administration of the drug or placebo, five minutes after salbutamol inhalation, and 15 minutes after administration of SCG solution or placebo; then immediately after exercise and at $1,3,5,15$, and 30 minutes and 1,2,3, and 4 hours after exercise. Only one exercise test was performed per day, and tests on the second and third days were performed only if the resting PEFR had fallen to within $20 \%$ of the resting PEFR on the first day for comparability. No medication was given for 12 hours before the tests, and all tests were performed in the early morning. Statistical analysis was carried out using a two-tail, paired Student's $t$ test.

\section{Results}

In three children bronchoconstriction occurred immediately after administration of placebo with falls of $5.3 \%, 10 \%$, and $4.5 \%$ in the respective resting PEFRs, while four children showed falls of $2 \cdot 3 \%$, $5.3 \%, 16.7 \%$, and $9.1 \% 15$ minutes later-that is, immediately before exercise. After administration of SCG the PEFR fell in three children by $11.1 \%, 16.7 \%$, and $4 \%$, but none of the group showed bronchoconstriction 15 minutes later. None of the children showed bronchoconstriction with salbutamol.

SCG produced bronchodilatation in the group as a whole before exercise with significantly raised PEFR both immediately and 15 minutes after administration (table). This bronchodilatation was enhanced after exercise, with the maximum mean PEFR occurring immediately after exercise $(P<0 \cdot 001)$, and was sustained throughout the study, the mean PEFR being still significantly raised four hours after exercise $(P<0.001)$. Salbutamol produced significant bronchodilatation at all times, with the highest mean PEFR occurring five minutes after exercise $(\mathbf{P}<0.001)$. Placebo produced a small degree of bronchodilatation before exercise, but the mean PEFR was not significantly higher than the mean resting value. Exercise, however, produced significant bronchodilatation, with the highest mean PEFR occurring one minute after exercise $(P<0.001)$. This bronchodilatation was short-lived, lasting no more than 15 minutes, and is the characteristic response of the asthmatic to a short period of exercise. ${ }^{6}$ At four hours after exercise the group showed bronchoconstriction, though not to a significant degree.

SCG and salbutamol produced bronchodilatation in similar degree with equal effectiveness up to four hours (figure). The means of the rise in PEFR with SCG and salbutamol were significantly higher than the mean rise with placebo at all times ( $P$ ranging from 0.005 to $<0.001$ ), while there was no significant difference in the mean rise in PEFR with SCG and salbutamol at all times.

\section{Discussion}

SCG has not been regarded as a bronchodilator. We have established that it has a bronchodilator action that is comparable in degree and duration with that of the powerful $\beta_{2}$ stimulant salbutamol. This raises the possibility that SCG may have a direct action on smooth muscle as well as the accepted action of inhibiting the release of chemical mediators from mast cells. In the presence of low-level antigen from ambient sources SCG is a potent inhibitor of exercise-induced bronchoconstriction, possibly acting on receptors in smooth muscle, as it does not seem possible to explain this inhibitory action by its effect on the

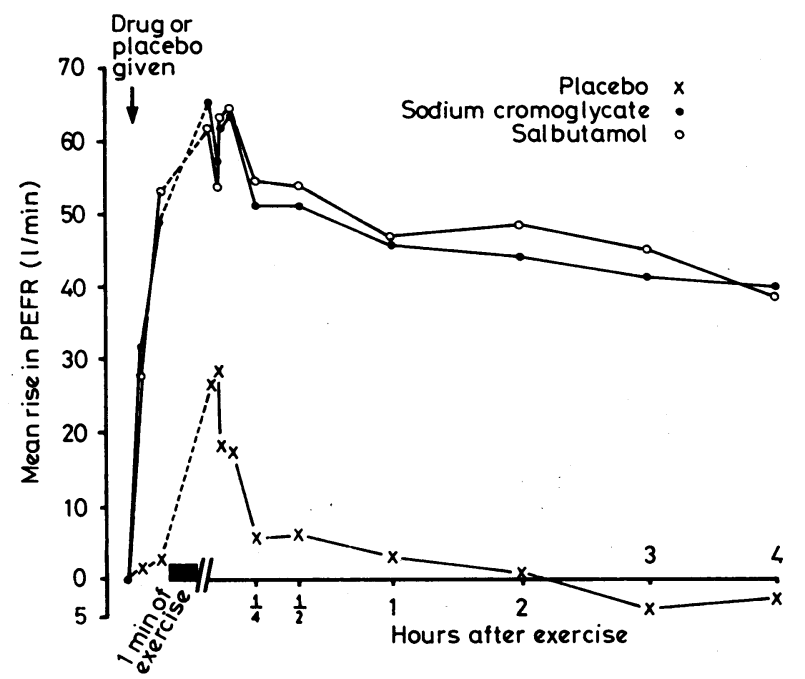

Change in peak expiratory flow rate (PEFR) before and after exercise.

mast cell alone. ${ }^{5}$ This suggestion accords with experimental evidence. ${ }^{7}$ The bronchodilator effect of SCG and its inhibitory action on exercised-induced bronchoconstriction may perhaps be closely interrelated and act along common pathways. There have been isolated reports of bronchoconstriction in adults and in a child provoked by inhalation of SCG, ${ }^{8-11}$ but no report of bronchodilatation in adults has emerged. This raises the possibility that children and adults may have different physiological responses to SCG.

The actions of SCG that we have described were achieved by using the solution and an efficient nebuliser. The important clinical implication from our study is that for maximum effect the drug has to be given in the form of solution delivered by an efficient mains-driven nebuliser.

\section{References}

${ }^{1}$ Cox, J S G, in Disodium Cromoglycate in Allergic Airways Disease, ed J Pepys and A W Frankland. London, Butterworths, 1970.

2 Morton, A R, and Fitch, K D, Medical fournal of Australia, 1974, 2, 158.

${ }^{3}$ Godfrey, J, and König, P, Thorax, 1976, 31, 137.

4 Silverman, M, and Andrea, T, Archives of Disease in Childhood, 1972, 47, 419.

5 Jones, R S, and Chung, J T N, in The Mast Cell-its Role in Health and Disease. Tunbridge Wells, Pitman Medical. In press.

6 Jones, R S, Buston, M H, and Wharton, M J, British fournal of Diseases of the Chest, 1962, 56, 78.

7 Jackson, D M, and Richards, I M, British fournal of Pharmacology, 1977, 61, 257.

8 Paterson, I C, Grant, I W, and Crompton, G K, British Medical fournal, $1976,2,916$.

${ }^{9}$ Linzmayer, I, and Ishikawa, S, Clinical Research, 1975, 23, 599A.

10 Johnson, A J, American Review of Respiratory Disease, 1977, 115, 60.

11 Menon, M P S, and Das, A K, Scandinavian fournal of Respiratory Diseases, 1977, 58, 145.

(Accepted 16 August 1979)

Comparison of mean $( \pm S D)$ peak expiratory flow rates (PEFRs) at rest with values after administration of placebo and drugs (l/min)

\begin{tabular}{|c|c|c|c|c|c|c|c|c|}
\hline & & & $\begin{array}{c}\text { At rest } \\
\text { before } \\
\text { administration }\end{array}$ & $\begin{array}{c}\text { Immediately } \\
\text { after } \\
\text { administration }\end{array}$ & $\begin{array}{c}\text { Immediately } \\
\text { before } \\
\text { exercise* }\end{array}$ & $\begin{array}{l}\text { Highest value } \\
\text { after exercise } \\
(0-5 \mathrm{~min})\end{array}$ & $\begin{array}{c}15 \text { minutes } \\
\text { after } \\
\text { exercise }\end{array}$ & $\begin{array}{l}4 \text { hours } \\
\text { after } \\
\text { exercise }\end{array}$ \\
\hline \multicolumn{9}{|c|}{ Placebo } \\
\hline $\begin{array}{l}\text { PEFR } \\
\text { Significance }\end{array}$ & $\because$ & $\because$ & $259 \cdot 5 \pm 94 \cdot 5$ & $\begin{array}{l}261.0 \pm 95.8 \\
0.6>\mathbf{P}>0.5\end{array}$ & $\begin{array}{c}262.0 \pm 98.2 \\
0.6>\mathrm{P}>0.5\end{array}$ & $\begin{array}{c}287.3 \pm 99.4 \\
P<0.001\end{array}$ & $\begin{array}{c}265 \cdot 0 \pm 98 \cdot 1 \\
P=0.3\end{array}$ & $\begin{array}{c}256.5 \pm 97.8 \\
P=0.6\end{array}$ \\
\hline $\begin{array}{l}\text { PEFR } \\
\text { Significance }\end{array}$ & $\begin{array}{l}. \\
.\end{array}$ & $\because$ & $250 \cdot 8 \pm 81 \cdot 9$ & $\begin{array}{c}282.3 \pm 87.3 \\
0.005>\mathrm{P}>0.001\end{array}$ & $\begin{array}{c}\text { Sodium cromoglycate } \\
300 \cdot 3 \pm 83 \cdot 3 \\
\mathbf{P}<0 \cdot 001 \\
\text { Salbutamol }\end{array}$ & $\begin{array}{c}316.5 \pm 82.7 \\
P<0.001\end{array}$ & $\begin{array}{c}302.5 \pm 84.5 \\
P<0.001\end{array}$ & $\begin{array}{c}\mathbf{P}<0 \cdot 001 \\
\end{array}$ \\
\hline $\begin{array}{l}\text { PEFR } \\
\text { Significance }\end{array}$ & $\because$ & $\because$. & $250 \cdot 8 \pm 87 \cdot 7$ & $\begin{array}{c}278.3 \pm 84.5 \\
\mathbf{P}<0.001\end{array}$ & $\begin{array}{c}304 \cdot 3 \pm 86 \cdot 8 \\
P<0 \cdot 001\end{array}$ & $\begin{array}{c}315.3 \pm 86.4 \\
P<0.001\end{array}$ & $\begin{array}{c}305.5 \pm 89.5 \\
P<0.001\end{array}$ & $\begin{array}{c}289.0 \pm 86.7 \\
P<0.001\end{array}$ \\
\hline
\end{tabular}

*Time after administration was 15 minutes for placebo and sodium cromoglycate and five minutes for salbutamol. 